\title{
A transboundary transport episode of nitrogen dioxide as observed from GOME and its impact in the Alpine region
}

\author{
D. Schaub ${ }^{1}$, A. K. Weiss ${ }^{1}$, J. W. Kaiser ${ }^{2}$, A. Petritoli ${ }^{3}$, A. Richter ${ }^{4}$, B. Buchmann ${ }^{1}$, and J. P. Burrows ${ }^{4}$ \\ ${ }^{1}$ Swiss Federal Lab. for Materials Testing \& Research (EMPA), Ueberlandstrasse 129, CH-8600 Duebendorf, Switzerland \\ ${ }^{2}$ Remote Sensing Laboratories, University of Zurich, Winterthurerstrasse 190, CH-8057 Zurich, Switzerland \\ ${ }^{3}$ Institute of Atmospheric Science and Climate (ISAC-CNR), Via Gobetti 101, I-40129 Bologna, Italy \\ ${ }^{4}$ Institute of Environmental Physics, University of Bremen, P.O. Box 3304 40, D-28334 Bremen, Germany
}

Received: 21 June 2004 - Published in Atmos. Chem. Phys. Discuss.: 8 September 2004

Revised: 13 December 2004 - Accepted: 27 December 2004 - Published: 12 January 2005

\begin{abstract}
High tropospheric $\mathrm{NO}_{2}$ amounts are occasionally detected by space-borne spectrometers above cloudy scenes. For monitoring of near-ground air pollution such data are not directly applicable because clouds shield the highly polluted planetary boundary layer (PBL). We present a method based on trajectories which implicitly estimates the additional subcloud $\mathrm{NO}_{2}$ distribution in order to model concentrations at ground stations. The method is applied to a transboundary pollution transport episode which led to high $\mathrm{NO}_{2}$ vertical tropospheric column densities (VTCs) over middle Europe observed by the Global Ozone Monitoring Experiment (GOME) instrument above clouds on 17 February 2001. The case study shows that pollution originally residing near the ground in central Germany, the Ruhr area and adjacent parts of the Netherlands and Belgium has been advected to higher tropospheric levels by a passing weather front. Combining the above-cloud $\mathrm{NO}_{2}$ VTCs with trajectory information covering the GOME columns and including their sub-cloud part yields an estimate of the total $\mathrm{NO}_{2}$ distribution within the tropospheric columns. The highly polluted air masses are then traced by forward trajectories starting from the GOME columns to move further to the Alpine region and their impact there is assessed. Considering ground-based in-situ measurements in the Alpine region, we conclude that for this episode, at least $50 \%$ of the $\mathrm{NO}_{2}$ concentration recorded at the sites can be attributed to transboundary transport during the frontal passage. This study demonstrates the potential of using $\mathrm{NO}_{2}$ VTCs from GOME detected above clouds when combined with transport modelling.
\end{abstract}

Correspondence to: D. Schaub

(daniel.schaub@empa.ch)

\section{Introduction}

Nitrogen dioxide $\left(\mathrm{NO}_{2}\right)$ plays a key role in photochemical air pollution. Its amount and distribution is of significance directly for air quality and human health and indirectly as an ozone precursor (e.g. Seinfeld and Pandis, 1998). Therefore, for air quality policy, accurate source attribution and impact assessment is required.

\section{$1.1 \quad \mathrm{NO}_{2}$ chemistry}

$\mathrm{NO}_{2}$ is formed according to the photochemical equilibrium on a time scale of minutes from the primarily emitted nitrogen oxide (NO), the bulk of which is of anthropogenic origin (Brasseur, 2003). The $\mathrm{NO}_{2}$ concentration at any time and place is determined by the emission of $\mathrm{NO}_{\mathrm{x}}\left(\equiv \mathrm{NO}+\mathrm{NO}_{2}\right)$, its production and loss reactions as well as meteorological transport and dilution. Furthermore, the $\mathrm{NO}_{2}$ concentration is affected by the partitioning of $\mathrm{NO}_{\mathrm{x}}$ into $\mathrm{NO}$ and $\mathrm{NO}_{2}$ which depends on the meteorological conditions, the abundance of reactive organic compounds and the altitude in the troposphere. During the Transport and Chemical Evolution over the Pacific (TRACE-P) campaign between February and April 2001 (Jacob et al., 2003), the bulk of the $\mathrm{NO} / \mathrm{NO}_{2}$ ratios have been found to be around 0.25 at near-ground levels (Nakamura et al., 2003). Similar values from different campaigns can be found in Warneck (2000). Ratios of up to 1 are found in the middle troposphere (Nakamura et al., 2003).

$\mathrm{NO}_{2}$ is removed from the troposphere through conversion to nitric acid $\left(\mathrm{HNO}_{3}\right)$ which deposits (Kramm et al., 1995). During daytime, $\mathrm{HNO}_{3}$ emanates from the reaction of $\mathrm{NO}_{2}$ with the $\mathrm{OH}$ radical. During night time, $\mathrm{NO}_{2}$ reacts with ozone to form the $\mathrm{NO}_{3}$ radical, the latter further reacting with $\mathrm{NO}_{2}$ to $\mathrm{N}_{2} \mathrm{O}_{5}$. Nitrogen pentoxide subsequently reacts on surfaces and aerosol to $\mathrm{HNO}_{3}$ (Dentener and Crutzen, 1993). Although diurnal variations of the $\mathrm{NO}_{2}$ lifetime are

(C) 2005 Author(s). This work is licensed under a Creative Commons License. 
considerable and may be only a few hours during photochemically active summer days, the average boundary layer lifetime during the whole year is estimated to be in the order of one day (Warneck, 2000). Leue et al. (2001) used vertical tropospheric $\mathrm{NO}_{2}$ column densities observed from GOME over the eastern coast of North America to estimate an $\mathrm{NO}_{2}$ lifetime of 27 hours in the planetary boundary layer (PBL). Following the plume leaving the coast of India, Kunhikrishnan et al. (2004) estimated a lifetime of $18 \mathrm{~h}$. However, in the middle and upper troposphere, decreasing $\mathrm{OH}$ and aerosol concentrations lead to a longer $\mathrm{NO}_{2}$ lifetime being of the order of several days to a week (Jaeglé et al., 1998; Seinfeld and Pandis, 1998; Warneck, 2000). Thus, $\mathrm{NO}_{2}$ may be transported over larger distances once it is lifted to higher tropospheric levels, for example by frontal systems.

\subsection{Previous observations}

For high-alpine sites, the importance of meteorological transport processes such as frontal advection on the variability of trace gases has been shown. For example, Forrer et al. (2000) investigated among others the variability of $\mathrm{NO}_{\mathrm{x}}$ at the highalpine site Jungfraujoch and found that during such events, $\mathrm{NO}_{\mathrm{x}}$ concentrations can increase from below $1 \mathrm{ppb}$ up to around $10 \mathrm{ppb}$. Such frontal episodes have been found to significantly increase the monthly mean concentrations during the whole year, most pronounced during winter months. Further investigations at our institute have distinguished between background and polluted conditions at the high-alpine site Jungfraujoch based on classifying trajectories. It has been found that around one third of the days at this site are affected by synoptical lifting and frontal pollution transport causing an average $\mathrm{NO}_{\mathrm{x}}$ concentration increase in the order of $100 \%$.

Numerical model results have shown synoptic-scale vertical advection to be a significant transport mechanism for nitrogen oxides (Hov and Flatoy, 1997). In agreement with this, more than $50 \%$ of a passive tracer released in the boundary layer was found to be transported to the free troposphere within $24 \mathrm{~h}$ during a frontal passage (Donnell et al., 2001). Aircraft campaigns have verified that significant quantities of trace gases are lifted up from the PBL into the free troposphere by a warm conveyor belt associated with the frontal system (Bethan et al., 1998). The importance of synoptic uplift and subsequent long-range transport of trace gases for air pollution monitoring was shown by Stohl et al. (2002).

The retrieval of the tropospheric $\mathrm{NO}_{2}$ column from spaceborne instrumentation has become available since the launch of the GOME instrument (Burrows et al., 1999) aboard the European Space Agency (ESA) satellite ERS-2 (Earth Remote Sensing Satellite). GOME measurements were successfully used to observe intercontinental transport events of nitrogen dioxide (Spichtinger et al., 2001; Wenig et al., 2003; Stohl et al., 2003). Therefore, combining satellite and ground-based data with transport models is useful to observe transport phenomena influencing the $\mathrm{NO}_{2}$ distribution.

\subsection{Present study}

We present a method to quantify air pollution transport based on trajectory analysis by using tropospheric $\mathrm{NO}_{2}$ observed from GOME above clouds instead of emission inventories. The method is applicable for high $\mathrm{NO}_{2}$ columns observed from GOME above an extended cloud cover where lightning $\mathrm{NO}_{\mathrm{x}}$ can be excluded and, thus, a frontal transport episode is postulated to have advected near-ground pollution above the cloud cover. Because the trajectories cover the whole GOME column including its sub-cloud part, the method implicitly estimates the $\mathrm{NO}_{2}$ distribution within the whole column.

In this paper, an episode of "intracontinental" transport of nitrogen dioxide is investigated for a cloudy scene on 17 February 2001. First, the source region of the pollution detected from GOME is assessed with backward trajectories. Forward trajectories are used to estimate potential impact regions of the pollution transport. Employing a higher number of trajectories and the GOME $\mathrm{NO}_{2}$ VTCs the $\mathrm{NO}_{2}$ transport and its impact in the Alpine region is identified quantitatively and compared to ground-based in-situ measurements.

\section{Measurement data}

\subsection{GOME measurements}

The GOME instrument aboard ESA's ERS-2 satellite measures upwelling radiance from the atmosphere and extraterrestrial solar irradiance. The amount and distribution of a variety of significant atmospheric trace constituents may be retrieved from these observations (Burrows et al., 1999). It was designed and optimised primarily to measure the global ozone distribution, but also the amounts of the trace gases $\mathrm{BrO}, \mathrm{OCIO}, \mathrm{H}_{2} \mathrm{O}, \mathrm{HCHO}$ and $\mathrm{NO}_{2}$ can be obtained.

The GOME instrument comprises a nadir-viewing spectrometer which observes simultaneously the entire spectral range between 240 and $793 \mathrm{~nm}$ at channel dependent spectral resolutions between 0.2 and $0.4 \mathrm{~nm}$. From the spectral features of the trace gases, their vertical columns are retrieved (e.g. Richter and Burrows, 2002). Because of its sun-synchronous polar orbit, GOME measurements in middle latitudes are always taken in the late morning local time. With its swath width of $960 \mathrm{~km}$ (single ground pixel size is $320 \mathrm{~km}$ across track and $40 \mathrm{~km}$ along track) GOME reaches full coverage at the mid-latitudes within 2-3 days.

The $\mathrm{NO}_{2}$ vertical tropospheric column density (VTC) data used in this study were provided by the University of Bremen (Richter and Burrows, 2002). Uncertainties in the VTCs are due to the $\mathrm{NO}_{2}$ fitting algorithm, instrument characteristics, the method of the stratosphere-troposphere separation and atmospheric parameters such as the a priori $\mathrm{NO}_{2}$ profile shape, the surface spectral reflectance, the aerosol loading and the 
clouds. These atmospheric parameters account for the largest part of the uncertainties. Richter and Burrows (2002) and Boersma et al. (2004) carried out detailed error analysis for the $\mathrm{NO}_{2}$ VTCs and found a total uncertainty of up to a factor of 2. In order to reduce the uncertainty, the GOME data used in the present study were reprocessed with an adapted cloud top height $(\mathrm{CTH})$ and an assumed location of the $\mathrm{NO}_{2}$ layer. Furthermore, different scenarios for the structure of the cloud cover (closed cloud cover and partly cloudy taking into account cloud mask data) are used.

\subsection{Ground-based in-situ measurements}

The Swiss National Air Pollution Monitoring Network (NABEL) provides long-term ambient air measurements (EMPA, 2002; BUWAL, 2002). To investigate the impact of the mesoscale transport process, rural and remote sites located in the Swiss Plateau or elevated and north-exposed stations are suitable as the air mass inflow during this episode is from northern to north-eastern direction.

Data from the following sites (Fig. 1) are used in this study:

A) Rigi $\left(47^{\circ} 04^{\prime} \mathrm{N}, 8^{\circ} 28^{\prime} \mathrm{E}, 1030 \mathrm{~m}\right.$ a.s.l.): A rural site that is well suited for detection of events advected from northern direction, because it is situated on a north-exposed mountain slope. In winter, local influences arising from thermal transport are rare.

B) Chaumont $\left(47^{\circ} 03^{\prime} \mathrm{N}, 6^{\circ} 59^{\prime} \mathrm{E}, 1140 \mathrm{~m}\right.$ a.s.l. $)$ :

This site is also situated at an elevated location at some distance from cities and is surrounded by meadows and grassland. The nearest industrial enterprises are situated 5 to $10 \mathrm{~km}$ away.

C) Taenikon $\left(47^{\circ} 28^{\prime} \mathrm{N}, 8^{\circ} 54^{\prime} \mathrm{E}, 540 \mathrm{~m}\right.$ a.s.l.):

A site that samples air from the Swiss Plateau. The surroundings are dominated by agriculture and forests, the highway A1 lies in north-eastern direction at a distance of $4 \mathrm{~km}$.

D) Zugspitze $\left(47^{\circ} 25^{\prime} \mathrm{N}, 10^{\circ} 59^{\prime} \mathrm{E}, 2963 \mathrm{~m}\right.$ a.s.l.):

This site is located at the northern rim of the Alps and, therefore, suitable for the detection of air masses advected from the North (Umweltbundesamt, 2002). It is used because no measurements from the high-alpine site Jungfraujoch (Switzerland) are available during the time of the case study.

At these sites, nitrogen oxides are measured with the ozone chemiluminescence detectors Monitor Labs (ML) 8841 (Rigi), ML 9841 A (Chaumont), ECO Physics CLD 700 (Taenikon) and TE 42 Thermo Environmental Systems/TECAN (Zugspitze). All measurement devices are equipped with a molybdenum converter. It should be noted that these catalytic surface converters are sensitive not only to $\mathrm{NO}_{2}$, but also to other nitrogen species such as PAN, $\mathrm{HNO}_{2}$,

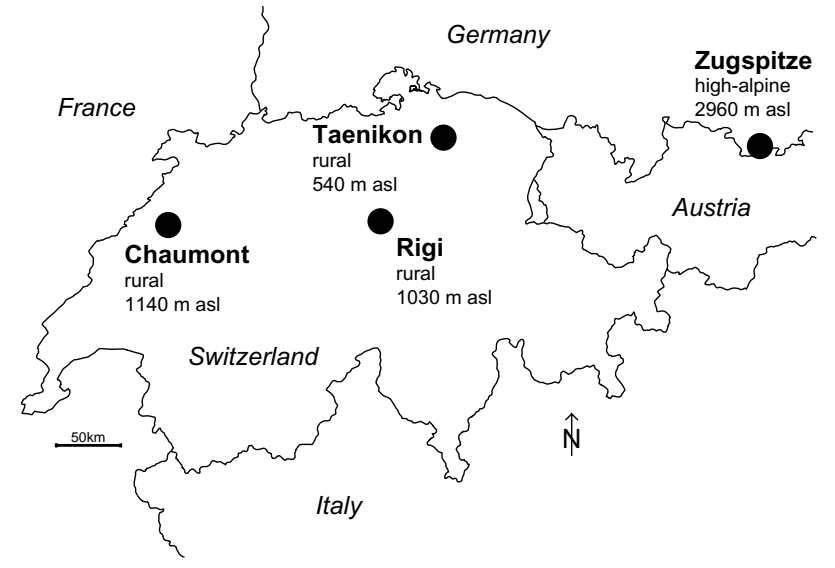

Fig. 1. The location of the three remote ground-based measurement stations operated by the Swiss National Air Pollution Monitoring Network (NABEL) and the Zugspitze station (Umweltbundesamt, 2002) which are used in this case study.

$\mathrm{HNO}_{3}$ and particulate nitrate to NO. Generally, the PAN mixing ratio can be expected to be small during winter conditions. Wunderli and Gehrig (1991) found a mean February PAN mixing ratio at Davos (Switzerland, 1640 meters asl) of $0.1 \mathrm{ppb}$. Under cold and clear weather conditions, however, elevated PAN mixing ratios were measured in winter with an evening maximum at Davos of $0.6 \mathrm{ppb} . \mathrm{HNO}_{2}$ is rapidly transformed to $\mathrm{OH}$ and $\mathrm{NO}$ by photolysis and mixing ratios are normally below the detection limit during the day (Winer and Biermann, 1994). Maximum February/March $\mathrm{HNO}_{3}$ concentrations were found to be in the order of $0.3 \mathrm{ppb}$ at Jungfraujoch (Zellweger et al., 2003) and 0.8 ppb in Duebendorf (Zellweger et al., 1999) at $3580 \mathrm{~m}$ a.s.1. and $430 \mathrm{~m}$ a.s.l., respectively. Particulate nitrate exhibits large temporal and spatial variations and might have the strongest influence on the interference. In March 1997, Zellweger et al. (1999) measured nitrate concentrations of up to $5.5 \mathrm{ppb}$ at the Swiss Plateau station Duebendorf. February measurements at the high-alpine site Jungfraujoch indicated maximum concentrations of $0.3 \mathrm{ppb}$ during weak thermal transport events and much lower values when thermal transport is absent (Zellweger et al., 2003). As the $\mathrm{NO}_{2}$ mixing ratios are between 5 (high-alpine) and $30 \mathrm{ppb}$ (Swiss Plateau) in this case study, we consider the interference of the above discussed nitrogen species to have a minor influence.

\section{Methods}

\subsection{Trajectory calculations}

Backward and forward trajectories are used to investigate the origin of the detected air masses in the studied GOME columns and their further movement. The trajectories are 
based on analysed wind fields with a six hour temporal and $1^{\circ} \times 1^{\circ}$ geographical resolution provided by the model of the European Centre for Medium-Range Weather Forecast (ECMWF). Three dimensional kinematic backward and forward trajectories are calculated with the software package "Lagranto" (Wernli and Davies, 1997). Their length is chosen to be long enough for source and impact analysis (several days). The $\mathrm{NO}_{2}$ distribution within the GOME columns is unknown. Therefore, the backward/forward trajectory arrival/starting points cover the GOME columns both horizontally and vertically in order to account for its whole tropospheric volume $(320 \mathrm{~km} \times 40 \mathrm{~km} \times$ tropopause height $)$.

For a first assessment of the source regions and the further air mass movement (Sects. 4.3 and 4.4), each column is covered with 70 arrival/starting points; 10 levels from $900 \mathrm{hPa}$ up to $400 \mathrm{hPa}$ in $50 \mathrm{hPa}$ steps, each level containing 7 points. For a quantitative transport assessment (Sects. 3.2 and 4.6), a much higher density of backward and forward trajectories is calculated for each GOME column with 128 (4 along track $\times 32$ across track) arrival/starting points in the horizontal for 23 height levels between $950 \mathrm{hPa}$ and $400 \mathrm{hPa}$ in $25 \mathrm{hPa}$ steps (resulting in a total of 2944 trajectories per column). The arrival/starting time point for the case study is chosen to be on 17 February 2001, 9:00 UTC corresponding to the GOME overpass at around 10:15 local time.

\subsection{Transport model based on trajectories and GOME ob- servations}

A transport model based on backward and forward trajectories, GOME $\mathrm{NO}_{2}$ VTCs above a cloudy scene, population distribution data, and an assumed average $\mathrm{NO}_{2}$ lifetime is employed to estimate the amount of advected $\mathrm{NO}_{2}$ at ground measurement sites. The method comprising three steps is discussed in detail in the following sections and is illustrated in Fig. 2. Firstly, the population number is added up (as a proxy for $\mathrm{NO}_{2}$ emissions), transported along the backward trajectories and corrected for the $\mathrm{NO}_{2}$ lifetime (Sect. 3.2.1). Secondly, the $\mathrm{NO}_{2}$ proxy arriving in the GOME columns is summed vertically above different $\mathrm{CTH}$. These proxy VTCs are compared to the GOME $\mathrm{NO}_{2}$ VTCs in order to identify an effective $\mathrm{CTH}\left(\mathrm{CTH}_{e f f}\right)$ where the modelled above-cloud pollution best reproduces the detected pollution from GOME. Relating the proxy VTCs above $\mathrm{CTH}_{e f f}$ to the GOME $\mathrm{NO}_{2}$ VTCs yields a conversion factor. Using the latter, the proxy is converted to number of $\mathrm{NO}_{2}$ molecules (Sect. 3.2.2). Thirdly, the $\mathrm{NO}_{2}$ polluted air masses is traced with forward trajectories, corrected for the $\mathrm{NO}_{2}$ lifetime and converted into $\mathrm{NO}_{2}$ mixing ratios when trajectories reach near-ground levels (Sect. 3.2.3).

\subsubsection{Pollution uptake and $\mathrm{NO}_{2}$ lifetime correction}

The $\mathrm{NO}_{2}$ uptake along the backward trajectories is simulated by passing the trajectories over a $1^{\circ} \times 1^{\circ}$ resolved popula- tion grid (UNEP: Global Population Distribution Database, http://grid2.cr.usgs.gov/globalpop, 1997) assuming the $\mathrm{NO}_{2}$ emission to be proportional to the population in the respective grid cell. Following the trajectory forward in time, pollution is taken up when the trajectory reaches a nearground level of less then an assumed PBL height above model ground. In this case, the number of the population in the respective grid cell is added up along the trajectory as a proxy for $\mathrm{NO}_{2}$ emissions. In order to account for the enhanced $\mathrm{NO}_{\mathrm{x}}$ emissions during daytime, the night time uptake is weighted with a factor of 0.5 , whereas the daytime uptake is multiplied with a factor of 1.5. Further, the $\mathrm{NO}_{2}$ proxy transported along the trajectory is decreasing every time step according to an assumed average $\mathrm{NO}_{2}$ lifetime.

It must be mentioned that the bulk of $\mathrm{NO}_{\mathrm{x}}$ is emitted as NO. Further, the partitioning of $\mathrm{NO}_{\mathrm{x}}$ into $\mathrm{NO}$ and $\mathrm{NO}_{2}$ is dependent on the meteorological conditions (and therefore the season), the pollution situation and the abundance of reactive organic compounds shifting the photostationary steady state (Warneck, 2000, and references therein). Nevertheless, we henceforth allude to $\mathrm{NO}_{2}$ (emissions), because the $\mathrm{NO}_{\mathrm{x}}$ partitioning is - due to the conversion described in Sect. 3.2.2 circumstantial for the further analysis shown here. Thus, the implicit assumptions are made that (i) emission sources are similar concerning the $\mathrm{NO}_{\mathrm{x}}$ partitioning and that (ii) the $\mathrm{NO}_{\mathrm{x}}$ partitioning during the investigated episode is similar within the transported air parcels.

\subsubsection{Conversion of $\mathrm{NO}_{2}$ proxy to number of $\mathrm{NO}_{2}$ molecules}

Each backward trajectory arrives in its appropriate GOME column containing a population number as a proxy for $\mathrm{NO}_{2}$. This quantity is converted to a number of $\mathrm{NO}_{2}$ molecules by applying a conversion factor. The latter is deduced from relating the sum of the considered GOME $\mathrm{NO}_{2}$ VTCs detected above the clouds to the appropriate sum of the proxy VTCs above the cloud cover. As in this way also the $\mathrm{NO}_{2}$ proxy below the clouds is converted, this step implicitly estimates the $\mathrm{NO}_{2}$ distribution within the whole column including its sub-cloud part. However, two main issues complicate this approach:

1. The sensitivity of the GOME instrument for $\mathrm{NO}_{2}$ within the column is not constant. For a cloudy pixel, the sensitivity is maximal at the $\mathrm{CTH}$ and decreases for $\mathrm{NO}_{2}$ situated above or within the cloud (Hild et al., 2002).

2. Near-ground trajectories based on a $1^{\circ} \times 1^{\circ}$ resolved wind field might not properly reproduce the (frontal) air mass movement.

This prevents the straightforward use of the real CTH above which the proxy VTCs can be calculated. To account for both, we define a $\mathrm{CTH}_{e f f}$ where the modelled above-cloud pollution (proxy VTCs) best reproduces the pollution pattern 


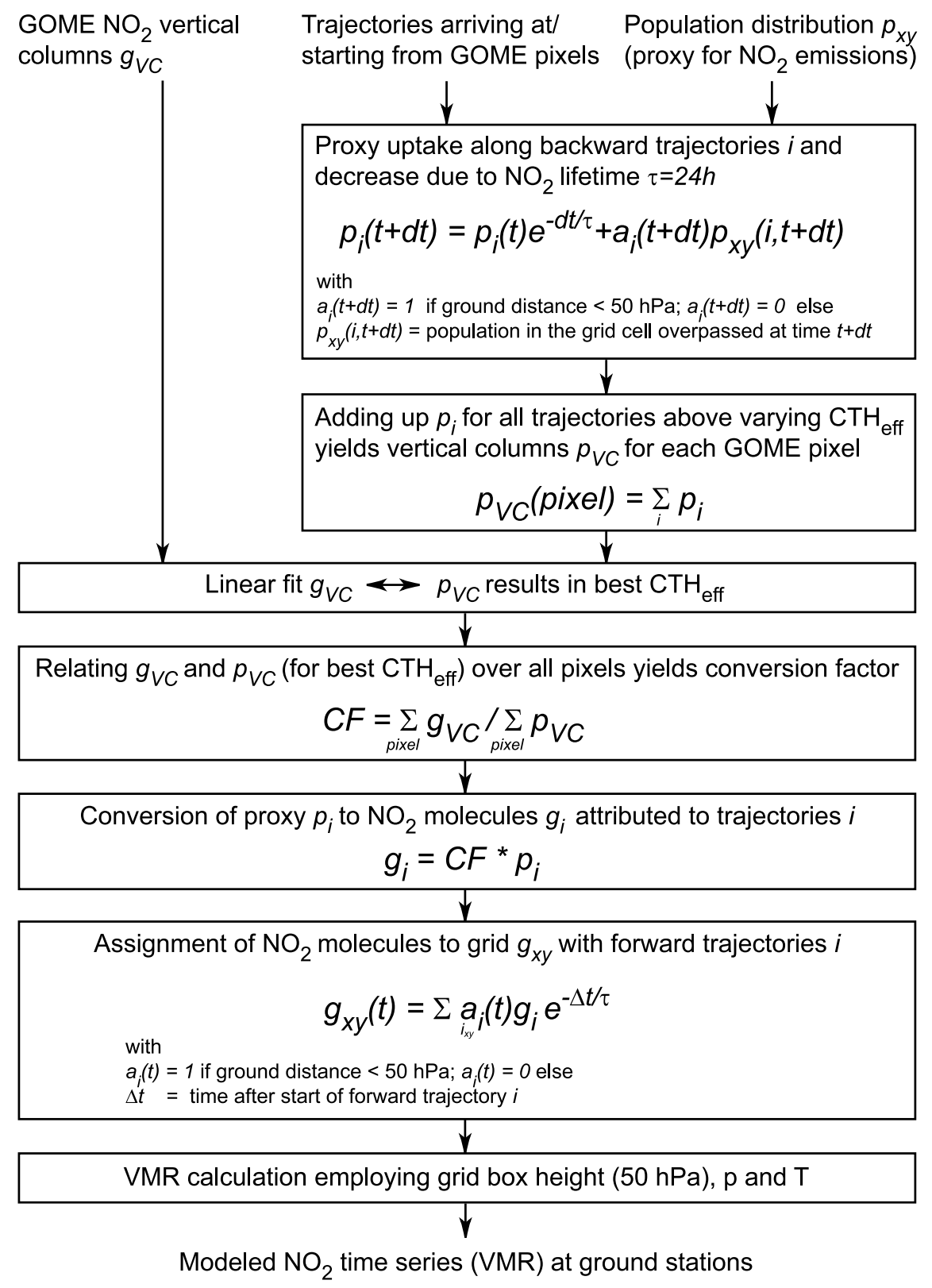

Fig. 2. Flow chart illustrating the proposed method (Sect. 3.2) to model $\mathrm{NO}_{2}$ mixing ratios at ground, employing population numbers assigned to the trajectories and subsequent conversion with $\mathrm{GOME} \mathrm{NO}_{2}$ vertical tropospheric column densities $(\mathrm{VTCs})$. $(\mathrm{CTH} \mathrm{Cff}=\mathrm{effective}$ cloud top height, $\mathrm{VMR}=$ volume mixing ratio, $\mathrm{VC}=$ vertical column, pixel=GOME pixel).

detected from GOME $\left(\mathrm{NO}_{2}\right.$ VTCs). Because GOME sees to some extent into the clouds, the $\mathrm{CTH}_{\text {eff }}$ is expected to be lower than the real CTH. The CTH is assumed to be constant across the considered GOME pixels (Fig. 3c). Linearly fitting the proxy VTCs above different CTHs with the real GOME $\mathrm{NO}_{2}$ VTCs yields the adequate $\mathrm{CTH}_{\text {eff }}$ where the explained variance $\mathrm{R}^{2}$ maximizes.

\subsubsection{Pollution propagation, $\mathrm{NO}_{2}$ lifetime and conversion} to $\mathrm{NO}_{2}$ mixing ratios at ground stations

The $\mathrm{NO}_{2}$ is modelled to propagate further along the forward trajectories. Again, the $\mathrm{NO}_{2}$ loading is decreasing every time step according to the assumed average $\mathrm{NO}_{2}$ lifetime. As soon as the trajectories reach near-ground levels, the impact on the $\mathrm{NO}_{2}$ concentration there can be assessed by assigning the $\mathrm{NO}_{2}$ values of the trajectories to appropriate grid cells superimposed over the region of interest (for the investigated 

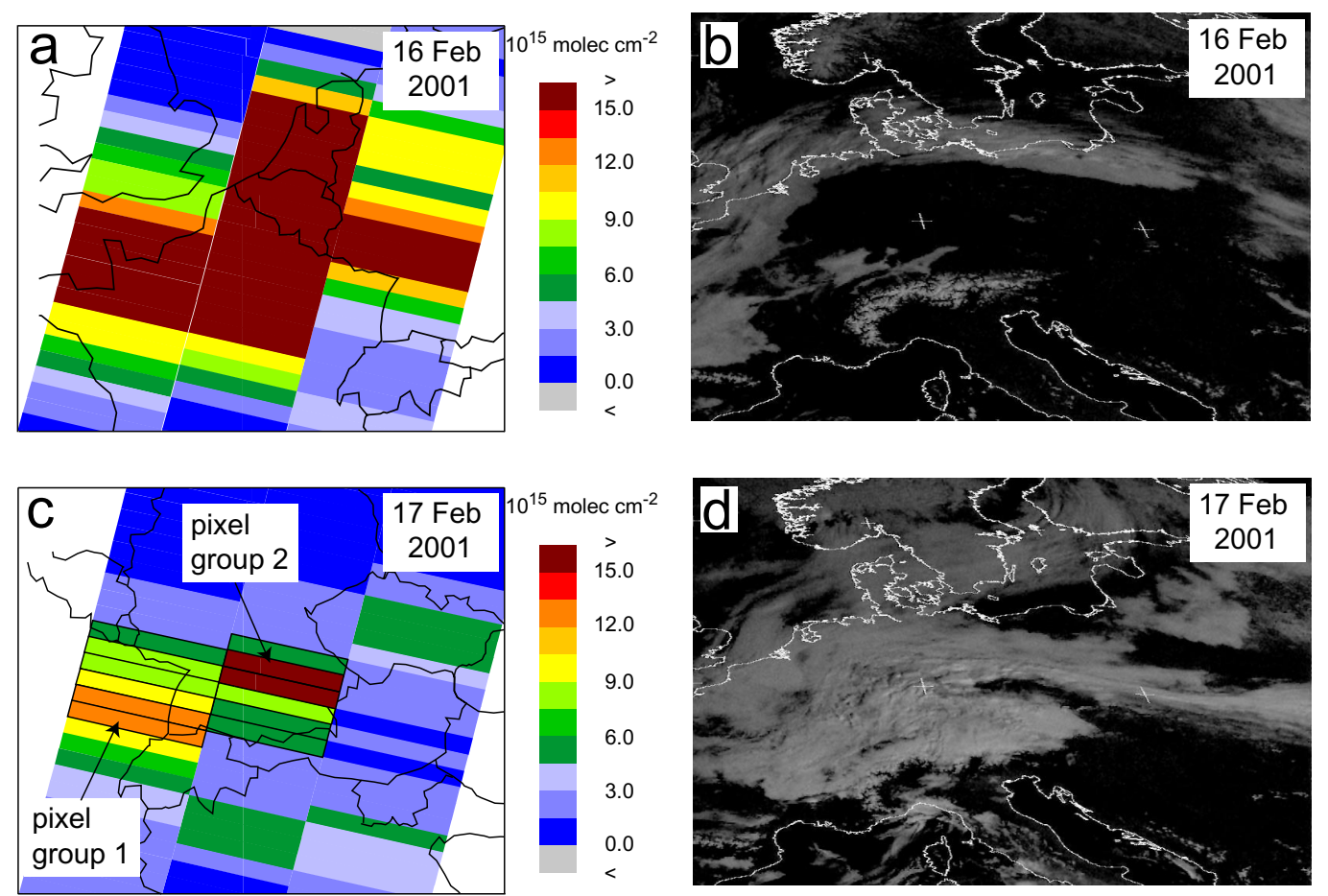

Fig. 3. (a) GOME track on 16 February, 2001, indicating high $\mathrm{NO}_{2}$ VTCs over France, Belgium, the Netherlands and Germany. (b) Meteosat visible wavelength image detected at 9:30 am UCT on 16 February, 2001. (c) GOME track on 17 February, 2001, showing high NO 2 VTCs above clouds. For the highest values (pixel groups 1 and 2, each consisting of 2 GOME pixels) trajectories are discussed qualitatively. The transport model calculation is based on all of the 12 framed pixels found relevant for the investigated air mass. (d) Meteosat visible wavelength image detected at 9:30 am UTC on 17 February, 2001, indicating the extended cloud cover over middle Europe.

episode a $0.5^{\circ} \times 0.5^{\circ}$ resolved grid is superimposed over the Alpine region). In a last step, the hourly resolved numbers of molecules in the grid cells corresponding to the measurement sites are recalculated to mixing ratios using temperature and pressure data and the vertical box extension. The vertical box extension (near-ground level) for the case study is defined in Sect. 4.6.2.

\subsubsection{Errors of the method}

Main error sources of the described approach are (i) the assumption of an average lifetime of $\mathrm{NO}_{2}$, (ii) the fact that a single air mass trajectory does not implicitly account for dilution, (iii) the error associated with the assumption of the population distribution being a representative proxy for $\mathrm{NO}_{\mathrm{x}}$ emissions, (iv) the assumption of a constant CTH and (v) the uncertainties in the GOME $\mathrm{NO}_{2}$ VTCs.

(i) Assuming an average lifetime for $\mathrm{NO}_{2}$ is a strong simplification given its complex atmospheric chemistry. Especially when transport occurs within a shorter time scale (within a few hours only), also differences between daytime and night time $\mathrm{NO}_{2}$ chemistry have to be considered. For the present case study investigating a transport episode of several days an average $\mathrm{NO}_{2}$ lifetime is assumed. In order to account for errors arising from this simplification, the sensi- tivity of the results with respect to the lifetime is tested (and no major impact is found, see Sect. 4.6.2). A relatively long lifetime $(24 \mathrm{~h})$ is chosen because the photolysis is relatively weak in winter due to the increased solar zenith angle (Dickerson et al., 1982; Parrish et al., 1983; Wiegand and Bofinger, 2000). Furthermore, the loss of $\mathrm{NO}_{2}$ through conversion with $\mathrm{OH}$ to $\mathrm{HNO}_{3}$ is slow because the amount of $\mathrm{OH}$ is low in winter (Seinfeld and Pandis, 1998). An average lifetime of one day can also be found in literature (Warneck, 2000) and is confirmed from assessments with tropospheric $\mathrm{NO}_{2}$ columns from GOME (Leue et al., 2001; Kunhikrishnan et al., 2004).

(ii) The dilution is to some extent taken into account by the large number of trajectories and their divergence. Furthermore, the effect of dilution can be expected to be rather weak for the frontal transport as it lifts up an extended air mass having enhanced $\mathrm{NO}_{2}$ concentrations and, thus, relatively small concentration gradients.

(iii) A basic assumption is that the population distribution constitutes a proxy for $\mathrm{NO}_{\mathrm{x}}$ emissions. This seems plausible taking into account the fact that $\mathrm{NO}_{\mathrm{x}}$ is mainly of anthropogenic origin (Brasseur et al., 2003). Although $\mathrm{NO}_{\mathrm{x}}$ emissions along highways also take place outside the population centres, this error is expected to be of minor influence 

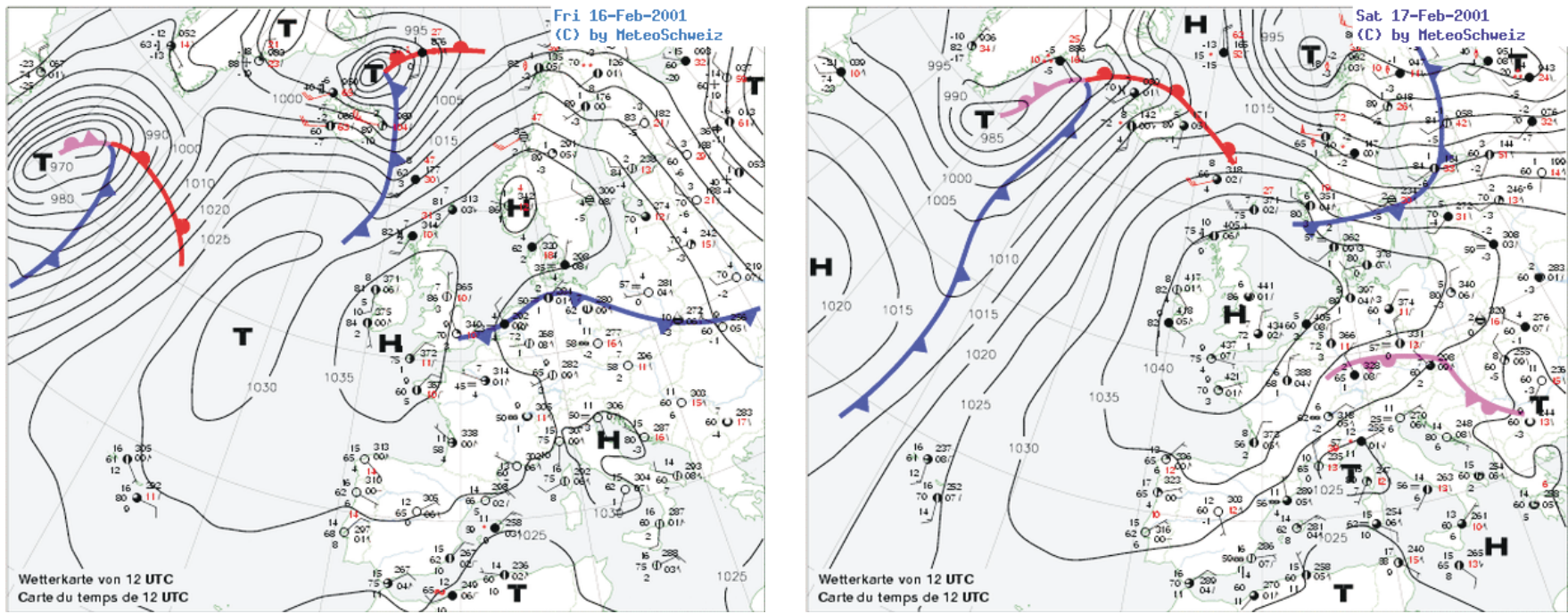

Fig. 4. Weather maps showing the southward moving cold front on 16 February 2001 (left) developing into an occlusion on 17 February (right) approaching the Alpine region.

because the population data are based on a relatively coarse resolved grid. This means that busy highways can be thought to be located around the population centres.

(iv) The CTH is essential for the described method and large inhomogeneities in the CTH must be considered. For the present study, the inspection of recent satellite data (KNMI, personal communication) indicates a rather uniform cloud cover over the considered GOME pixels and therefore, in this study, the assumption of a constant $\mathrm{CTH}$ is made.

(v) The error of the GOME $\mathrm{NO}_{2}$ VTCs can be reduced by reprocessing the data considering the occurrence of clouds.

\section{Case study - results and discussion}

\subsection{GOME observation on 17 February 2001}

GOME recorded high $\mathrm{NO}_{2}$ VTC values over central Europe on 17 February, 2001 (Fig. 3c). As can be seen in the Meteosat image (Fig. 3d), clouds shielded the ground. Therefore, a significant amount of nitrogen dioxide has to be located within and/or above the cloud cover. However, as pointed out by Richter and Burrows (2002), Leue et al. (2001) and Hild et al. (2002), the albedo effect of underlying clouds can increase the $\mathrm{NO}_{2}$ signal. Therefore, a reprocessing of the GOME $\mathrm{NO}_{2}$ VTCs is carried out using an assumed $\mathrm{NO}_{2}$ layer, the $\mathrm{CTH}$, and the structure of the cloud cover. A closed cloud cover is assumed in the reprocessing version $\mathrm{A}$. In version $\mathrm{B}$, cloud mask information is used and the total tropospheric column (where cloud free) and abovecloud columns are combined. On the basis of preliminary trajectory calculations, the $\mathrm{NO}_{2}$ is assumed to occur in a layer between 4000 and $6000 \mathrm{~m}$ a.s.l., whereas for standard pro- cessing an a priori $\mathrm{NO}_{2}$ profile with a constant mixing ratio in the lowermost $1.5 \mathrm{~km}$ of the troposphere is used (Richter and Burrows, 2002). For the underlying cloud cover, a height of $3000 \mathrm{~m}$ is assumed (which is accordance with live cams in the Alps). In fact, both the real vertical $\mathrm{NO}_{2}$ distribution and the CTH are not exactly known, but an inaccurate estimation of this heights turned out to be not very critical. The two reprocessing scenarios A and B yielded quite similar column values as shown in Table 1. Furthermore, the reprocessing results in distinctly lower values than the standard processing, which is due to the above mentioned albedo effect of the clouds (Richter and Burrows, 2002; Leue et al., 2001; Hild et al., 2002). For the further analysis, the overall cloudy case is used.

\subsection{Meteorological situation}

After a frontal passage on 13 February, a high pressure system installed over southern England and moved slowly to the east, causing the inflow of dry continental polar air to Switzerland during 14-16 February (from Alpine Weather Statistics (MeteoSwiss, 1985)). The flat pressure distribution associated with the high pressure system led to stagnating air over middle Europe. On 16 February, a coldfront formed over north-eastern Europe (Figs. 3b and 4) and moved southward, developing to an occlusion during 17 February (Figs. 3d and 4).

Cold-fronts are often associated with lightning activity, the latter being known to be an in-situ source of $\mathrm{NO}_{\mathrm{x}}$ in the free troposphere (e.g. Huntrieser et al., 2002). During the time of our case study, however, no lightning activity was recorded (www.wetterzentrale.de/topkarten/tkbeoblar.htm), and $\mathrm{NO}_{2}$ production by lightning can, therefore, be excluded. 
Table 1. GOME $\mathrm{NO}_{2}$ vertical tropospheric column densities (VTCs) for the standard processing and the two reprocessing scenarios A and B. The $\mathrm{NO}_{2}$ VTCs are the average values for the two pixel groups shown in Fig. 3c.

\begin{tabular}{llll}
\hline & standard processing & reprocessing A & reprocessing B \\
\hline $\mathrm{NO}_{2}$ profile & $\begin{array}{l}\text { standard a priori profile, constant } \\
\text { mixing ratio in the lowermost 1.5 km } \\
\text { (Richter and Burrows, 2002) }\end{array}$ & $\begin{array}{l}\mathrm{NO}_{2} \text { layer between } 4000 \\
\text { and } 6000 \mathrm{~m} \text { a.s.l. }\end{array}$ & $\begin{array}{l}\mathrm{NO}_{2} \text { layer between } 4000 \\
\text { and } 6000 \mathrm{~m} \text { a.s.l. }\end{array}$ \\
cloud cover & - & closed cloud cover & partly cloudy \\
Cloud top height & - & $3000 \mathrm{~m}$ a.s.l. & $3000 \mathrm{~m}$ a.s.1. \\
$\mathrm{NO}_{2}$ VTCs $\left[\times 10^{15} \mathrm{molec} \mathrm{cm}^{-2}\right]$ & 38 (pixel group 1) 64 (pixel group 2) & 13 (pixel group 1) 17.5 (pixel group 2) & 12 (pixel group 1) 16.5 (pixel group 2) \\
\hline
\end{tabular}
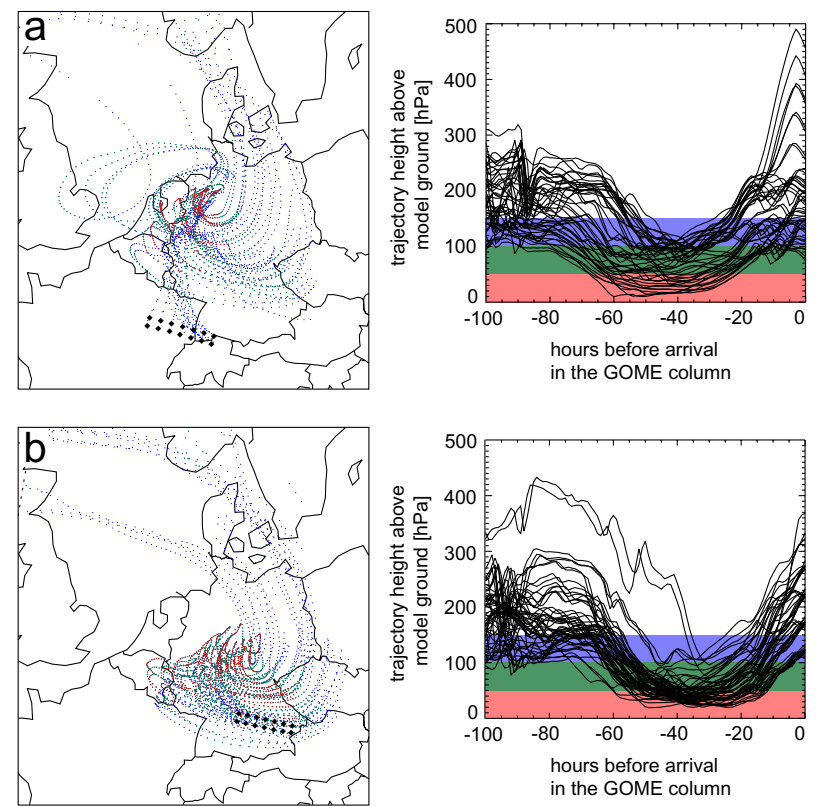

Fig. 5. Backward trajectories arriving on 17 February 2001, 9:00 UTC, in the two GOME pixel groups 1 (a) and 2 (b) defined in Fig. 3c. The coloured dots mark hourly trajectory time steps with a trajectory height above model ground of less than $150 \mathrm{hPa}$ (blue), less than $100 \mathrm{hPa}$ (green) and less than $50 \mathrm{hPa}$ (red), respectively. For clarity, in the horizontal projections, only trajectories with a distance from ground of less than $100 \mathrm{hPa}$ for at least one hourly time step are shown and trajectory points exceeding $150 \mathrm{hPa}$ ground distances are omitted. The source regions of the detected $\mathrm{NO}_{2}$ are likely to be located where the trajectories reside near the ground (red dots).

\subsection{Backward trajectories $-\mathrm{NO}_{2}$ source}

The source region of the air pollution detected by the GOME instrument is analysed with backward trajectories (Fig. 5), focusing on the two $\mathrm{NO}_{2}$ pixel groups (each composed of two GOME pixels as defined in Fig. 3c) over the border triangle of France, Germany and Switzerland (pixel group 1) and over south-eastern Germany (pixel group 2).
The trajectories indicate that the air masses arriving in the GOME columns are advected from western directions above the Northern Atlantic. They descend over Southern Scandinavia and the North Sea and subsequently turn clockwise over the region of the Netherlands, Belgium and Germany. This is a result of the presence of the high pressure system which installed over Europe before the frontal passage (Fig. 4). Near the ground, the vertical distribution of the trajectories is investigated in detail, because the residence time of an air parcel within the PBL allows the uptake of anthropogenic $\mathrm{NO}_{2}$. For better identification of the potential source regions, only trajectories residing at a ground distance of less than $100 \mathrm{hPa}$ for at least one (hourly) time step are considered in Fig. 5. Further, in the horizontal projections, time steps along these trajectories are omitted when their distance from ground exceeds $150 \mathrm{hPa}$. The potential source regions are most likely located where the trajectories travel near the ground, the latter indicated in Fig. 5 by trajectory time steps below $50 \mathrm{hPa}$ ground distance. Comparing these regions with the GOME $\mathrm{NO}_{2}$ VTCs on 16 February (Fig. 3a) shows a convincing coincidence between the regions with high $\mathrm{NO}_{2}$ VTCs and the potential source regions. For 15 February, no GOME track covering the appropriate region is available. The narrow spatial distances of the hourly time steps (red dots in Fig. 5) show that the air was rather stagnant during 15 and 16 February. As a result, the air parcels were exposed to $\mathrm{NO}_{\mathrm{x}}$ emissions for several hours in the highly populated region of the Netherlands, Belgium, Central Germany and the Ruhr area, the latter known to be one of the European hot spot regions concerning $\mathrm{NO}_{2}$ pollution (Leue et al., 2001; Beirle et al., 2003; Konovalov, 2004). The air mass trajectories then exhibit a sudden movement to southern direction associated with frontal uplifting (Fig. 5). These air masses are highly likely to be responsible for the enhanced $\mathrm{NO}_{2}$ in the pixel groups 1 and 2. The near-ground pollution reaches heights of up to $500 \mathrm{hPa}$ above surface pressure (Fig. 5). This corresponds to lifting up to up to $5000 \mathrm{~m}$ above model ground. Even higher levels were reached by air formerly travelling at a ground distance of more than $100 \mathrm{hPa}$.

Comparing the backward calculations for GOME pixel groups 1 and 2 indicates that the air from pixel group 2 over south-eastern Germany is more affected by polluted PBL air, 

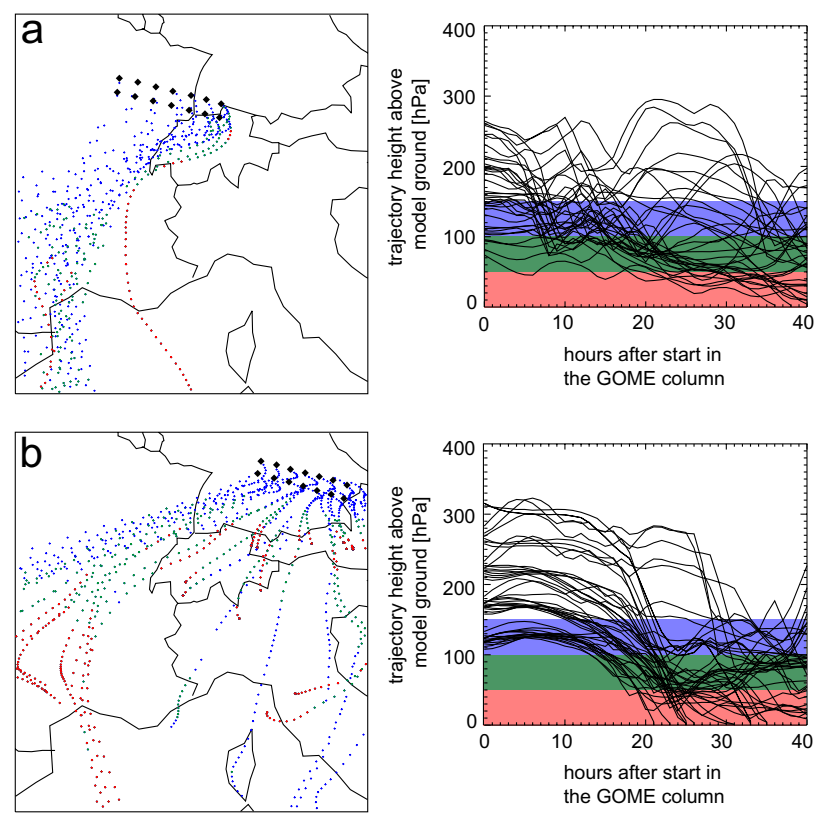

Fig. 6. The forward trajectories of the two GOME pixel groups 1 and 2 (defined in Fig. 3c) starting on 17 February 2001, 9:00 UTC, indicate the polluted air masses proceed to Switzerland and the Alpine region and further to south-west.

because the density of the trajectories at less than $50 \mathrm{hPa}$ is higher, and their uplifting takes place later. This explains the higher $\mathrm{NO}_{2}$ VTCs in these GOME columns.

\subsection{Forward trajectories - impact in the Alpine region}

The forward trajectories show that the polluted air masses detected by GOME move to the Alpine region including Switzerland (Fig. 6). For both GOME pixel groups, the forward trajectories' distance to the ground decreases again. This is explained by both an effective subsidence and the increasing altitude of the ground in southern direction. The air masses reach heights below $50 \mathrm{hPa}$ over the Alpine region (Fig. 6). The forward trajectories from GOME pixel group 1 stay relatively bundled and reach Switzerland in its north-western part. The trajectories from GOME pixel group 2 , however, show a much larger spread and the polluted air reaching Switzerland can therefore be expected to be more diluted.

\subsection{In-situ measurements in the Alpine region}

The February 2001 time series of $\mathrm{NO}_{2}$ measurements from the NABEL and Zugspitze stations indicate several events with high $\mathrm{NO}_{2}$, the two most outstanding ones around 7-8 and $17-18$ February (Fig. 7). The highest $\mathrm{NO}_{2}$ mixing ratio of this month was measured in the evening on 17 February at the Rigi station with a value of $30 \mathrm{ppb}$. The $\mathrm{NO}_{2}$ measurements at Chaumont and Zugspitze reached their maximum

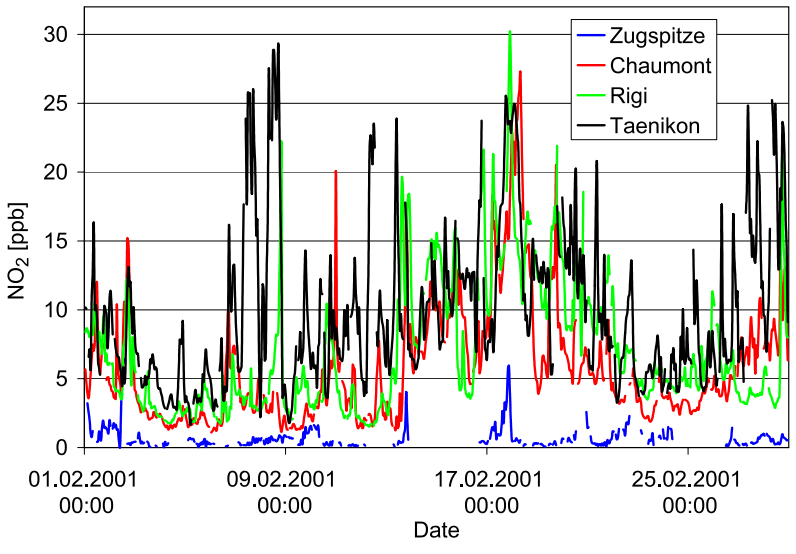

Fig. 7. $\mathrm{NO}_{2}$ mixing ratios measured at the NABEL ground stations Chaumont, Rigi and Taenikon and at the high-alpine site at Zugspitze in February 2001.

values at the same time with $27 \mathrm{ppb}$ and $6 \mathrm{ppb}$, respectively. At the Taenikon station, the highest value was measured on 8 February ( $29 \mathrm{ppb}$ ), but the value on the evening of 17 February is, nevertheless, a distinct event with $26 \mathrm{ppb} \mathrm{NO}_{2}$. What makes the event on 17-18 February special is the fact that all four stations show an almost simultaneous and significant increase in their nitrogen dioxide mixing ratios. This is in contrast to the event on 7-8 February, when very high $\mathrm{NO}_{2}$ values are limited to Taenikon. There, local pollution events are frequent due to the relatively near highway and the inversion layer above the Swiss Plateau which increases pollution concentrations especially in winter.

The simultaneous pollution event on 17 and 18 February and the similar mixing ratios at the Swiss sites cannot be explained by local sources, because these are strongly different in the north of each of the considered measurement stations. Furthermore, thermal uplifting, which is typical for elevated sites, is not likely to occur during the night and early morning hours, when the maximum $\mathrm{NO}_{2}$ mixing ratios were observed. Thus, the higher $\mathrm{NO}_{2}$ amounts measured at the elevated stations must be caused by larger scale meteorological transport of pollution. It is noteworthy that the maximum $\mathrm{NO}_{2}$ mixing ratios of $26 \mathrm{ppb}$ measured in Taenikon, $27 \mathrm{ppb}$ at Chaumont and $30 \mathrm{ppb}$ at Rigi are quite similar, even though the annual mean $\mathrm{NO}_{2}$ amounts show a pronounced decrease with increasing height (Taenikon: $7.0 \mathrm{ppb}$, Rigi: $4.8 \mathrm{ppb}$, Chaumont: 3.7 ppb (BUWAL, 2002)). These similar mixing ratios indicate a rather well mixed and extended air mass, the latter additionally confirmed by the simultaneous increasing mixing ratio at Zugspitze which is located about $290 \mathrm{~km}$ away from Rigi. These findings agree well with the above described air masses that have taken up pollution over an extended region and having been transported over mesoscale distances of several hundred kilometres. 

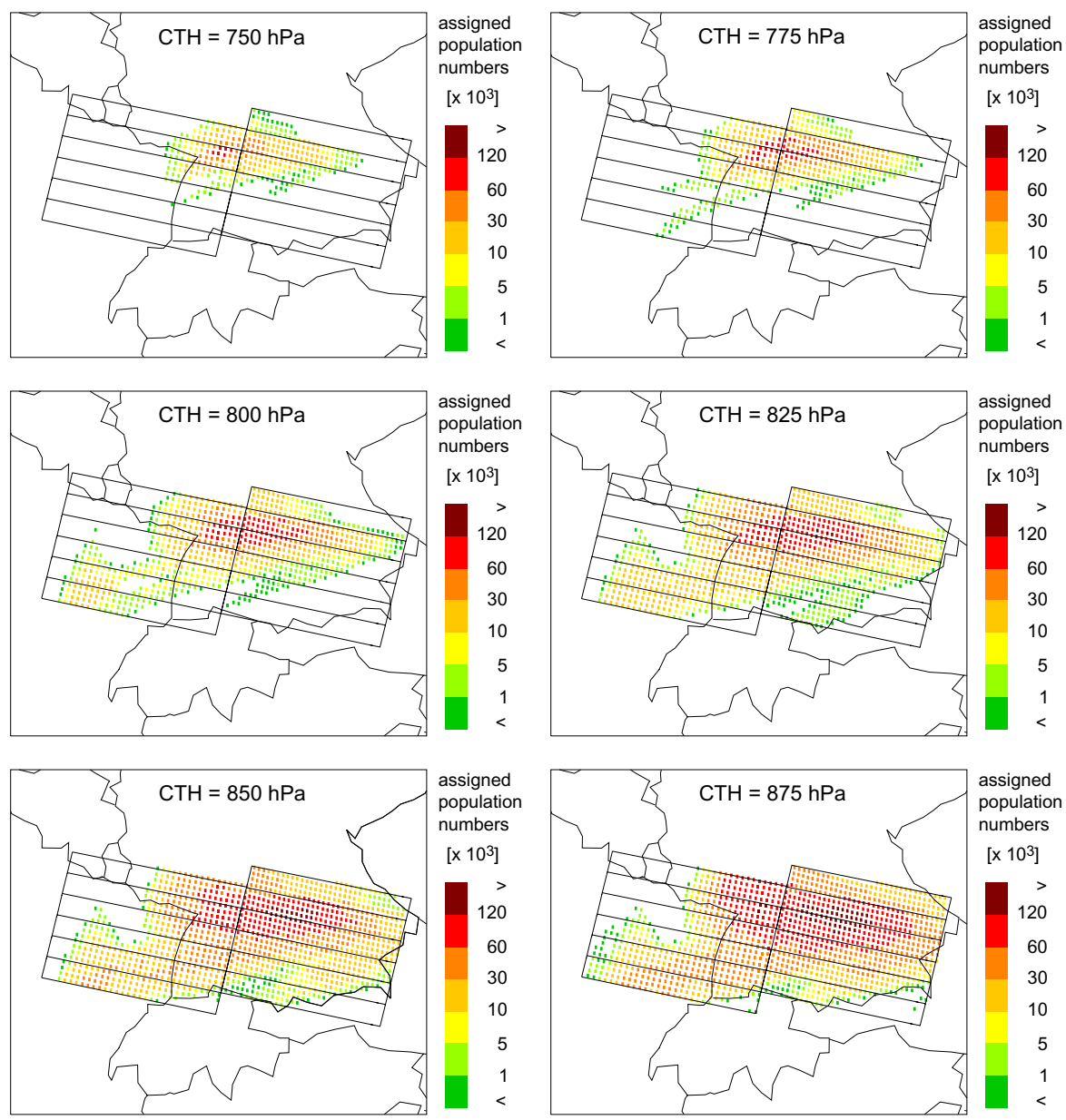

Fig. 8. Population numbers (assigned to the backward trajectories as a proxy for $\mathrm{NO}_{\mathrm{x}}$ emissions) added up above different cloud top heights (CTH) between $750 \mathrm{hPa}$ and $875 \mathrm{hPa}$ to a 2-dimensional proxy for the $\mathrm{NO}_{2}$ distribution above the clouds.

\subsection{Transport model}

4.6.1 Effective cloud top height and conversion with GOME observations

Our method proposed in Sect. 3.2 and illustrated in the flow chart of Fig. 2 is used to model the transport of $\mathrm{NO}_{2}$ for this case study. The core element of it is the conversion of population numbers assigned to the trajectories as a proxy for $\mathrm{NO}_{2}$ to number of $\mathrm{NO}_{2}$ molecules considering the GOME $\mathrm{NO}_{2}$ VTCs and the $\mathrm{CTH}_{e f f}$. As pointed out in Sect. 3.2.2, the latter is defined to be the CTH for which the modelled abovecloud pollution (proxy VTCs) best reproduces the detected pollution from GOME ( $\mathrm{NO}_{2}$ VTCs). Figure 8 illustrates an intermediate step where the population numbers assigned to the trajectories are added up above different CTH ranging between 750 and $875 \mathrm{hPa}$. This results in a 2-dimensional proxy for the $\mathrm{NO}_{2}$ distribution above the clouds. Especially when the CTH is in the range of 800 to $875 \mathrm{hPa}$ (which is lower than the real $\mathrm{CTH}$ ), the modelled $\mathrm{NO}_{2}$ distribution re- sembles the GOME observation (Fig. 3c). The band structure of high $\mathrm{NO}_{2}$ present in Fig. 8 agrees with the shape of the occlusion in Fig. 4 and indicates the uplift of previously ground-near pollution.

Summing the population numbers from Fig. 8 for each of the 12 considered GOME pixel locations (Fig. 3c) yields the $\mathrm{NO}_{2}$ proxy VTCs. They are related to the appropriate $\mathrm{NO}_{2}$ VTCs from GOME in order to determine the adequate $\mathrm{CTH}_{\text {eff }}$ for the further calculation. Figure 8 already indicates that the $\mathrm{CTH}_{e f f}$ must be located at a lower altitude because the pollution distribution detected from GOME (Fig. 3c) seems to be better reproduced at these CTHs. For a $\mathrm{CTH}$ of, e.g. $750 \mathrm{hPa}$, a poor linear fit between the two quantities can be expected: for some GOME pixel locations, no $\mathrm{NO}_{2}$ proxy is found above the clouds although the appropriate GOME columns show an enhanced $\mathrm{NO}_{2}$ amount (Figs. 8 and $3 \mathrm{c}$ ). Figure 9 shows the scatter plot between the two quantities for the CTH located at $850 \mathrm{hPa}$. For this CTH, a relatively good correlation and no offset is found between the proxy VTCs and the GOME $\mathrm{NO}_{2}$ VTCs although a constant 


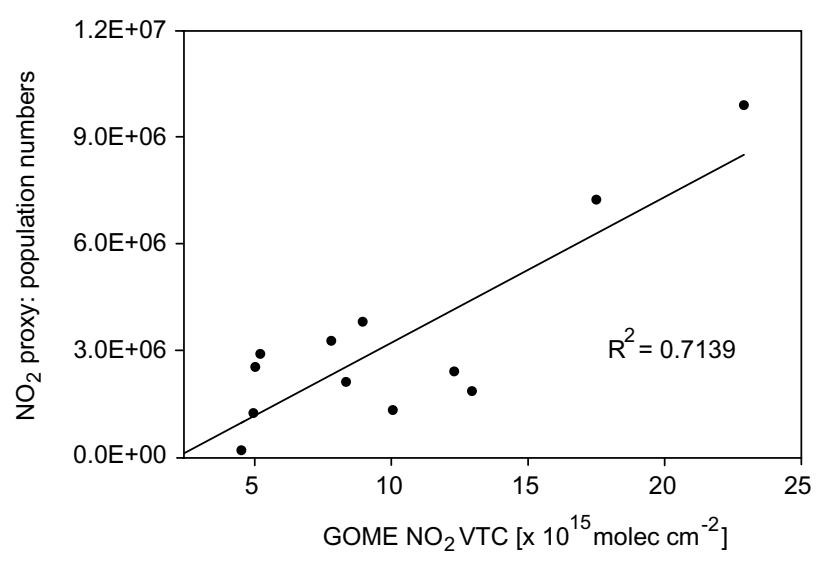

Fig. 9. Scatter plot and linear fit between vertical column proxy (population numbers) and appropriate GOME $\mathrm{NO}_{2}$ VTCs for a $\mathrm{CTH}$ of $850 \mathrm{hPa}$.

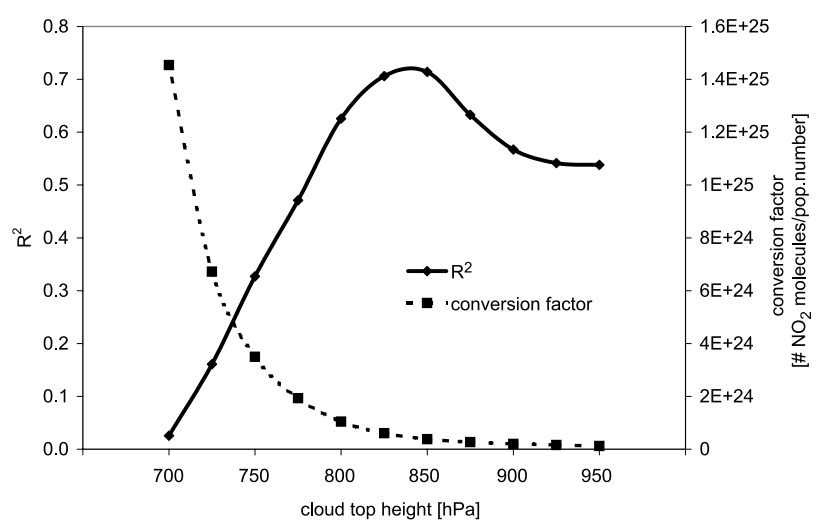

Fig. 10. Explained variance $\mathrm{R}^{2}$ of the linear fit between the proxy vertical column densities and the $\mathrm{GOME} \mathrm{NO}_{2}$ VTCs (solid line) and the respective conversion factors (dashed line) for different CTHs.

$\mathrm{CTH}$ has been assumed. This indicates the latter assumption to be not too far away from reality. This is also confirmed by an inspection of more recent satellite data (KNMI, personal communication) indicating that all the CTHs of the individual pixels lie in a range of within $8 \%$ around the mean CTH over the 12 considered GOME column locations of $693.5 \mathrm{hPa}$, the latter being very close to the assumption made in Sect. 4.1. Figure 10 summarises the explained variances $\mathrm{R}^{2}$ of the linear fits for different CTHs. As the $\mathrm{R}^{2}$-curve culminates at about $840 \mathrm{hPa}$, we use this $\mathrm{CTH}_{e f f}$ as the relevant level for our further calculation and use the 825 and $850 \mathrm{hPa}$ levels as the confidence interval.

The conversion factor is the ratio between the sum of the 12 GOME $\mathrm{NO}_{2}$ VTCs (Fig. 3c) and the sum of the respective 12 proxy VTCs (calculated above $\mathrm{CTH}_{\text {eff }}$ ). The conversion function showing the conversion factor for different CTHs (Fig. 10) indicates that small changes around $840 \mathrm{hPa}$ do not have a large impact on the results. With the conversion
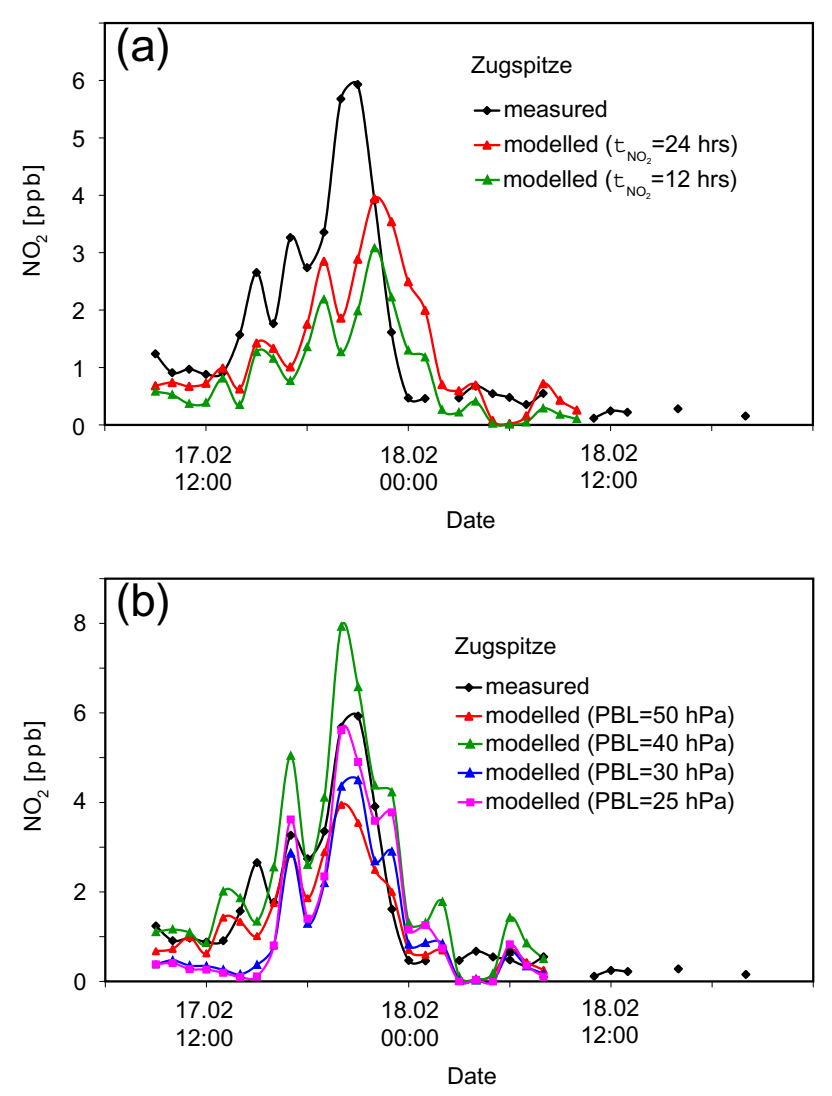

Fig. 11. (a) $\mathrm{NO}_{2}$ mixing ratios measured at the Zugspitze station during the investigated episode (black) and model results for the advected additional $\mathrm{NO}_{2}$ for an $\mathrm{NO}_{2}$ lifetime of $24 \mathrm{~h}$ (red) and of $12 \mathrm{~h}$ (green). (b) Measured $\mathrm{NO}_{2}$ mixing ratios (black) and model results for different assumptions on the planetary boundary layer (PBL) height. In order to simplify the visual assessment of the figure, the time shift of the modelled curves is neglected.

factor associated with $840 \mathrm{hPa}$, the population number of every trajectory is converted to an $\mathrm{NO}_{2}$ amount, which further propagates along the forward trajectory.

\subsubsection{Comparing in-situ measurements and modelled im- pact}

Below, the modelled $\mathrm{NO}_{2}$ concentrations are compared with the actual measurements at the ground stations. As pointed out in Sect. 3.2.3 the trajectories are defined to reach a ground measurement site as soon as they travel near the ground. The definition of the near-ground level, however, is not straightforward. The representation of the complex topography in the Alpine region can be thought to be relatively poor in the coarse resolved ECMWF model. Generally, trajectory modelling requires a height of a station to be not too far from the model topography for realistic results. For the present episode, the ECMWF model ground has been 960, 947, 906 and $875 \mathrm{hPa}$ for Taenikon (real surface pressure in winter 


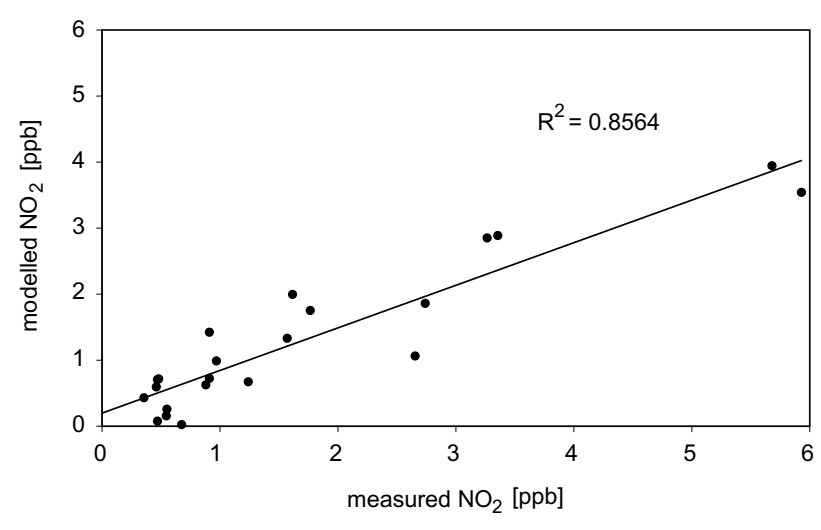

Fig. 12. Scatter plot and linear fit between the $\mathrm{NO}_{2}$ concentration measured at the ground station Zugspitze and the respective modelled $\mathrm{NO}_{2}$ mixing ratios for an assumed PBL height of $50 \mathrm{hPa}$ (and an $\mathrm{NO}_{2}$ lifetime of $24 \mathrm{~h}$ ).

around $950 \mathrm{hPa})$, Chaumont $(890 \mathrm{hPa})$, Rigi $(900 \mathrm{hPa})$ and Zugspitze $(700 \mathrm{hPa})$, respectively. For the first three stations, the box extension in which the trajectories are taken into account is defined to be up to $50 \mathrm{hPa}$ distance from model ground. For the Zugspitze, however, the model ground differs much more from the real height. Taking the real height of the site could thus lead to errors, because trajectories representing the free troposphere would be regarded as being representative for the Zugspitze. Therefore, the box representing the Zugspitze station is chosen to be located in distance of between $50 \mathrm{hPa}$ and $100 \mathrm{hPa}$ from model ground.

The model results for Zugspitze are shown, together with the measured time series of $\mathrm{NO}_{2}$, in Fig. 11. The modelled $\mathrm{NO}_{2}$ mixing ratios match the measured series surprisingly well (Fig. 11a). The measured variations in the $\mathrm{NO}_{2}$ mixing ratio are reproduced and the modelled maximum value of about $4 \mathrm{ppb}$ is in the order of the measured value of $6 \mathrm{ppb}$. Assuming that no local pollution occurred at this high-alpine site, the bulk of the $6 \mathrm{ppb} \mathrm{NO}_{2}$ can be considered as being due to frontal transport. This implies, that the model approach somewhat underestimates the transported $\mathrm{NO}_{2}$. The time shift of the modelled relative to the measured time series of about 1 to $2 \mathrm{~h}$ is most likely explained by inaccuracies in the near-ground trajectories.

Sensitivity studies concerning the average $\mathrm{NO}_{2}$ lifetime and the PBL height have been performed. Figure 11a includes the time series modelled for an average $\mathrm{NO}_{2}$ lifetime of 12 and of $24 \mathrm{~h}$ for Zugspitze. The comparison shows that this quantity has not a major impact on the results. Further calculations (not shown) indicated that for the other investigated sites, the differences due to different lifetimes are even smaller. Following the arguments pointed out in Sect. 3.2.4, an average lifetime of $24 \mathrm{~h}$ is chosen for the further calculation.
The assumed PBL height in the $\mathrm{NO}_{2}$ source region has been varied between 25 and $50 \mathrm{hPa}$. In Fig. 11b, the time shift is adjusted for better visualisation. The absolute values depend somewhat on the assumed height of the PBL and also on the vertical resolution of the trajectory model (in our case $25 \mathrm{hPa}$ ). The time series calculated for a $40 \mathrm{hPa}$ PBL indicate higher concentrations at the Zugspitze compared to the $50 \mathrm{hPa}$ PBL run. This is expected because a lower number of polluted trajectories arrive in the GOME columns at an altitude above the $\mathrm{CTH}_{e f f}$. Thus, the conversion factor increases. Further decreasing the PBL height leads to lower pollution also below the clouds which explains the decrease in the modelled concentrations for an assumed PBL of $30 \mathrm{hPa}$ compared to the $40 \mathrm{hPa}$ run. The best estimate for the PBL height is chosen via correlating the different resulting time series with the measured concentrations with the time shift adjusted. The best correlation is found for a PBL height of $50 \mathrm{hPa}$ (Fig. 12). Defining a near-ground layer of $50 \mathrm{hPa}$ corresponds to a PBL height of about $500 \mathrm{~m}$. This is rather high for winter conditions investigated in this episode. However, near the ground, trajectories are less accurate than at higher levels. This might be a reason for the best result emanating from modelling with a rather high PBL. Furthermore, mixing processes during the frontal movement associated with the southward transport described here complicates the proper definition of a PBL height.

Altogether, changing parameters such as the average $\mathrm{NO}_{2}$ lifetime and the PBL height does not change the results strongly (also valid for the other stations, not shown) because the conversion in the GOME columns compensates to some extent for different starting conditions. Thus, the results are relatively stable and indicate a successful use of the suggested method for this transport episode.

Figure 13 illustrates the measured (black) and modelled (red) $\mathrm{NO}_{2}$ time series for all the stations investigated in this study. Besides the result for the $\mathrm{CTH}_{\text {eff }}$ located at $840 \mathrm{hPa}$, the modelled concentrations for the two neighbouring levels with trajectory calculations in 850 and $825 \mathrm{hPa}$ are additionally shown as a confidence interval. The model output for Taenikon is less correlated with the measurement than seen for the Zugspitze station. At the beginning of the episode, the increasing mixing ratios are well shown by the model results, but the nearly constant values during the night are somewhat overestimated. However, the time range of the overall event is reproduced well and the order of magnitude of the $\mathrm{NO}_{2}$ mixing ratio is matched. For the two elevated sites at Rigi and Chaumont, the time series modelled for the grid cells corresponding to the sites did not explain the measured $\mathrm{NO}_{2}$ time series adequately. Taking into account adjacent grid cells, the time series found there match the measured mixing ratios much better, which might be due to uncertainties in the near-ground trajectories. The latter explanation is additionally supported by the fact that for both stations, the corresponding adjacent grid cells are found to be shifted towards the Swiss Plateau. This favours the following explanation: 

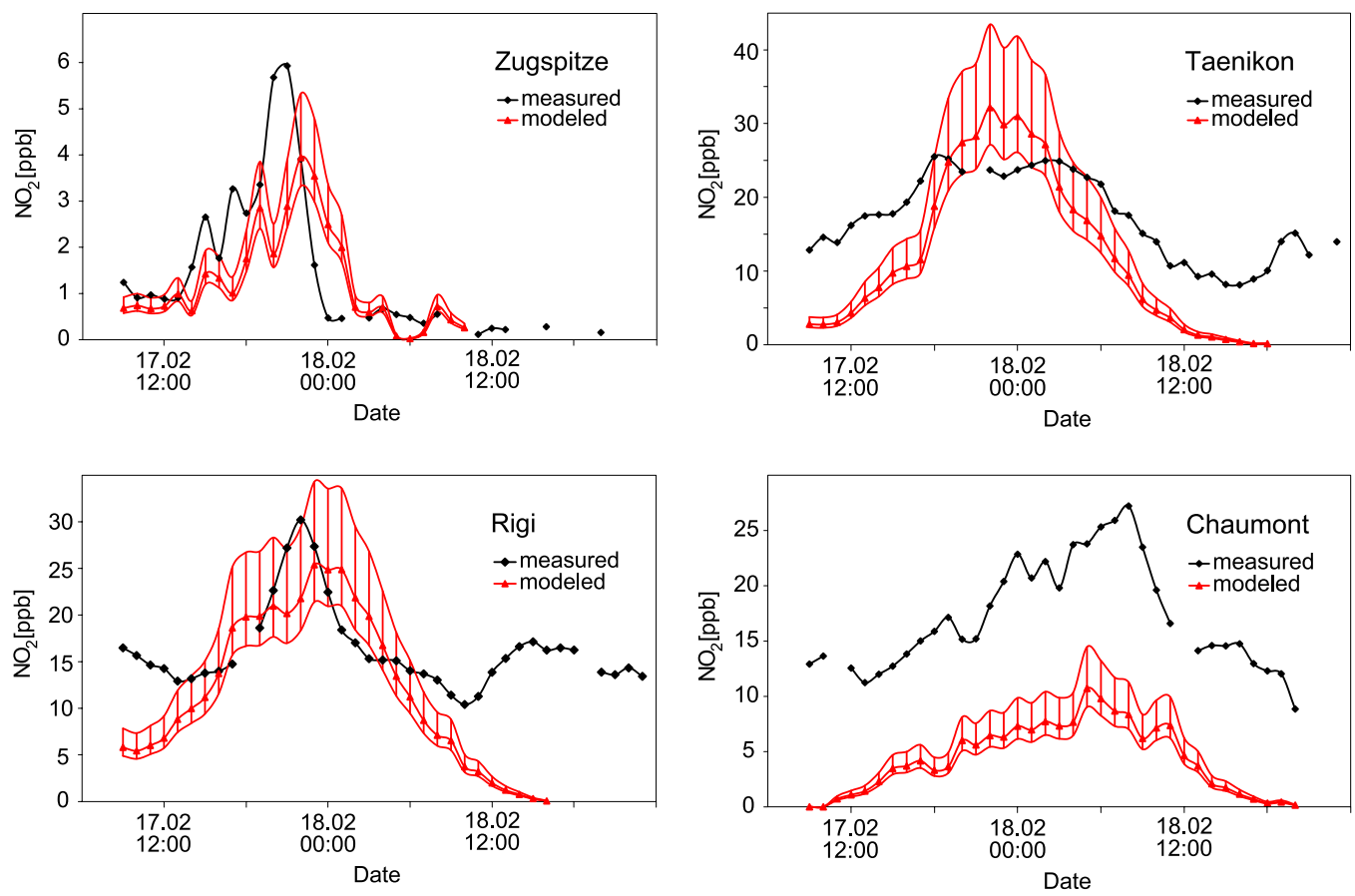

Fig. 13. $\mathrm{NO}_{2}$ mixing ratios measured during the investigated episode (black) and results of the model assessment of the advected additional $\mathrm{NO}_{2}$ (red). The thick red curve corresponds to the optimal $\mathrm{CTH}_{e f f}$ at $840 \mathrm{hPa}$, the thin curves from the adjacent (trajectory) levels in 825 (upper curve) and $850 \mathrm{hPa}$ (lower curve) are shown as a confidence interval. For the Zugspitze and Taenikon stations, the time series from the grid cells containing the measurement sites are used, whereas for Rigi and Chaumont, adjacent grid cells show more reliable results (see text).

the air mass flow is approximately parallel to the mountain ridges on which the two stations are located (the Jura Mountains for Chaumont and the foothills of the Alps for Rigi, Figs. 1 and 6). However, the complex Swiss topography strongly affecting the flow is not properly resolved in the ECMWF model with a resolution of $1^{\circ} \times 1^{\circ}$, displacing the near-ground trajectories somewhat. The modelled $\mathrm{NO}_{2}$ in the appropriate adjacent grid cells explain the shapes of the measured $\mathrm{NO}_{2}$ time series at Rigi and Chaumont quite reasonable although for the Chaumont station, the modelled mixing ratios are distinctly lower than the measured values. A reason for that could be that the Chaumont station is most affected by air masses from pixel group 1 (Figs. 1, 3c, and 6). Figure 6 indicates that the air from pixel group 2 has to cover a larger distance to reach this most western station and can, therefore, be expected to have a minor influence. The colours of pixel group 1 in Fig. 8 further show that the $\mathrm{NO}_{2}$ proxy for these two pixels might be somewhat underestimated by our method, because for this pixel group with the second highest column values (Fig. 3c), we would expect higher population numbers. This underestimation is probably due to the assumption of a cloud cover with a uniform height.

During the investigated episode, roughly 50 to $90 \%$ of the measured $\mathrm{NO}_{2}$ are found to be caused by transboundary transport. This seems plausible taking into account that the mean $\mathrm{NO}_{2}$ mixing ratios are much lower. The latter are determined by averaging the $\mathrm{NO}_{2}$ mixing ratios over the February months of the years 1999 to 2001 for the four stations (with the investigated period from 17 February, 0:00 MET, to 18 February, 12:00 MET, excluded). Typical night time $\mathrm{NO}_{2}$ mixing ratios from $0.5 \mathrm{ppb}$ at Zugspitze to about $5 \mathrm{ppb}$ for the elevated sites at Rigi and Chaumont are found. Only the Swiss Plateau station Taenikon shows evening mixing ratios exceeding $10 \mathrm{ppb}$.

Altogether we conclude from the comparison of the measured with the modelled $\mathrm{NO}_{2}$ mixing ratios that the GOME $\mathrm{NO}_{2}$ VTCs combined with our model can explain the exceptional events with high mixing ratios measured at the four sites and that the proposed method using above-cloud $\mathrm{NO}_{2}$ detected from space can successfully be applied.

\section{Summary and conclusions}

A method is presented to exploit enhanced tropospheric GOME $\mathrm{NO}_{2}$ measurements above extended cloud covers together with a trajectory based analysis to quantitatively assess air pollution transport. $\mathrm{A} \mathrm{NO}_{2}$ proxy is assumed to be proportional to the population distribution in the source region and is accumulated along ground-near trajectories considering an assumed average $\mathrm{NO}_{2}$ lifetime. After arriving 
at the locations of the GOME columns, the proxy vertical tropospheric column densities (VTCs) are calculated above different cloud top heights (CTHs). Comparing the latter with the GOME $\mathrm{NO}_{2}$ VTCs allows choosing the most appropriate effective cloud top height $\left(\mathrm{CTH}_{e f f}\right)$ where the pollution distribution from GOME is best reproduced by the model. Relating the proxy VTCs with the GOME $\mathrm{NO}_{2}$ VTCs yields a factor for converting the proxy to number of $\mathrm{NO}_{2}$ molecules. Because the transport model covers the whole tropospheric columns, this results in an implicit estimate of the $\mathrm{NO}_{2}$ distribution including its sub-cloud part. Further tracing the air masses with forward trajectories allows the estimation of pollution transport to other areas.

In a case study, the origin and impact of air pollution observed from the GOME instrument on 17 February 2001 above a cloud cover is investigated. Trajectory studies reveal that polluted boundary layer air was lifted up by a frontal system. This led to nitrogen dioxide being located within and/or above an extended cloud cover and therefore being detectable by the GOME instrument. The source region of the $\mathrm{NO}_{2}$ pollution is identified as the central part of Germany, the Ruhr area, and adjacent regions in the Netherlands and Belgium. Forward trajectory calculations indicate the subsequent movement of the polluted air masses to the Alpine region and predict that measurement stations in Switzerland and southern Germany are affected by the frontal transported $\mathrm{NO}_{2}$. Rural in-situ measurements of enhanced $\mathrm{NO}_{2}$ mixing ratios during the night confirm the prediction.

The $\mathrm{NO}_{2}$ transport to the Alpine area is modelled using the proposed method and compared with the ground-based measurements. The model successfully reproduced the measured time series and shows that at least $50 \%$ of the $\mathrm{NO}_{2}$ peak mixing ratios measured at the stations during the frontal passage can be attributed to transboundary transport. It is further demonstrated that the suggested method to convert the $\mathrm{NO}_{2}$ proxy into $\mathrm{NO}_{2}$ concentrations using $\mathrm{CTH}_{\text {eff }}$ and the appropriate above-cloud $\mathrm{NO}_{2}$ VTCs from GOME is stable in terms of changing parameters such as the average $\mathrm{NO}_{2}$ lifetime and the assumed boundary layer height.

The study shows the potential of pollution detected from space-borne spectrometers above cloudy scenes. For compounds measured in the visible spectral range (as, e.g. $\mathrm{NO}_{2}$ from GOME) this means that the lowest and often most polluted part of the troposphere is shielded from view. However, retrievals above clouds might be of better quality because of the enhanced sensitivity of satellite measurements above a strong reflector. The synergistic use of pollution detected above clouds and transport models in order to model pollution transport to ground stations is demonstrated in this study. It is planned to further improve the method by applying individual CTHs for every pixel (recently provided with satellite data). The enhanced spatial resolution of instruments such as SCIAMACHY further allows accounting for inhomogeneities in the CTH. It is intended to apply the described method on an extended data set of cloudy scenes observed from GOME and SCIAMACHY. This could further contribute to the issue of transboundary pollution transport and its impact at remote measurement sites.

Acknowledgements. This work was partly funded by the European Space Agency (ESA), the Swiss Federal Agency for Environment, Forest and Landscape (SAEFL) and the Swiss Federal Institute for Materials Testing and Research (EMPA). We gratefully acknowledge H. Wernli (ETH Zurich) for the software package "Lagranto" and for his support concerning trajectory calculation. We further acknowledge the Swiss National Air Pollution Monitoring Network (NABEL) and the Umweltbundesamt (Germany) for providing ground-based measurements, MeteoSwiss for the weather charts, the European Centre for Medium-Range Weather Forecast (ECMWF) for providing meteorological wind fields and the British Atmospheric Data Centre (BADC) for the Meteosat images.

Edited by: A. Volz-Thomas

\section{References}

Beirle, S., Platt, U., Wenig, M., and Wagner, T.: Weekly cycle of $\mathrm{NO}_{2}$ by GOME measurements: a signature of anthropogenic sources, Atmos. Chem. Phys., 3, 2225-2232, 2003,

SRef-ID: 1680-7324/acp/2003-3-2225.

Bethan, S., Vaughan, G., Gerbig, C., Volz-Thomas, A., Richer, H., and Tiddeman, D. A.: Chemical air mass differences near fronts, J. Geophys. Res., 103, 13 413-13 434, 1998.

Boersma, K. F., Eskes, H. J., and Brinksma, E. J.: Error analysis for tropospheric $\mathrm{NO}_{2}$ retrieval from space, J. Geophys. Res., 109, art. no. D04311, doi:10.1029/2003JD003962, 2004.

Brasseur, G. P.: Atmospheric chemistry in a changing world, Springer Verlag, Berlin, 2003.

Burrows, J. P., Weber, M., Buchwitz, M., Rozanov, V., LadstätterWeissenmayer, A., Richter, A., DeBeek, R., Hoogen, R., Bramstedt, K., Eichmann, K. U., Eisinger, M., and Perner, D.: The global ozone monitoring experiment (GOME): Mission concept and first scientific results, J. Atmos. Sci., 56, 151-175, 1999.

BUWAL: NABEL - Luftbelastung 2001, Schriftenreihe Umwelt Nr. 343, 2002.

Dentener, F. J. and Crutzen, P. J.: Reaction of $\mathrm{N}_{2} \mathrm{O}_{5}$ on tropospheric aerosols: impact on the global distributions of $\mathrm{NO}_{\mathrm{x}}, \mathrm{O}_{3}$ and $\mathrm{OH}$, J. Geophys. Res., 98, 7149-7163, 1993.

Dickerson, R. R., Stedman, D. H., and Delany, A. C.: Direct measurements of ozone and nitrogen-dioxide photolysis rates in the troposphere, J. Geophys. Res., 87, 4933-4946, 1982.

Donnell, E. A., Fish, D. J., Dicks, E. M., and Thorpe, A. J.: Mechanisms for pollutant transport between the boundary layer and the free troposphere, J. Geophys. Res., 106, 7847-7856, 2001.

EMPA: Technischer Bericht zum Nationalen Beobachtungsnetz für Luftfremdstoffe (NABEL), Duebendorf, 2002.

Forrer, J., Rüttimann, R., Schneiter, D., Fischer, A., Buchmann, B., and Hofer, P.: Variability of trace gases at the high-Alpine site Jungfraujoch caused by meteorological transport processes, J. Geophys. Res., 105, 12 241-12 251, 2000.

Hild, L., Richter, A., Rozanov, V., and Burrows, J. P.: Air mass factor calculations for GOME measurements of lightning-produced $\mathrm{NO}_{2}$, Adv. Space Res., 29, 1685-1690, 2002. 
Hov, O. and Flatoy, F.: Convective redistribution of ozone and oxides of nitrogen in the troposphere over Europe in summer and fall, J. Atmos. Chem., 28, 319-337, 1997.

Huntrieser, H., Feigl, C., Schlager, H., Schroder, F., Gerbig, C., van Velthoven, P., Flatoy, F., Thery, C., Petzold, A., Holler, $\mathrm{H}$., and Schumann, U.: Airborne measurements of $\mathrm{NO}_{\mathrm{x}}$, tracer species, and small particles during the European lightning nitrogen oxides experiment, J. Geophys. Res., 107, art. no. 4113, doi:10.1029/2000JD000209, 2002.

Jacob, D. J., Crawford, J., Kleb, M. M., Connors, V. S., Bendura, R. J., Raper, J. L., Sachse, G. W., Gille, J., Emmons, L., and Heald, J. C.: Transport and Chemical Evolution Over the Pacific (TRACE-P) mission: Design, execution, and first results, J. Geophys. Res., 108, art. no. 9000, doi:10.1029/2002JD003276, 2003.

Jaeglé, L., Jacob, D. J., Wang, Y., Weinheimer, A. J., Ridley, B. A., Campos, T. L., Sachse, G. W., and Hagen, D. E.: Sources and chemistry of $\mathrm{NO}_{\mathrm{x}}$ in the upper troposphere over the United States, Geophys. Res. Lett., 25, 1705-1708, 1998.

Konovalov, I. B., Beekmann, M., Vautard, R., Burrows, J. P., Richter, A., Nüss, H., and Elansky, N.: Comparison and evaluation of modelled and GOME measurement derived tropospheric $\mathrm{NO}_{2}$ columns over Western and Eastern Europe, Atmos. Chem. Phys. Discuss., 4, 6503-6558, 2004,

\section{SRef-ID: 1680-7375/acpd/2004-4-6503}

Kramm, G., Dlugi, R., Dollard, G. J., Foken, T., Mölders, N., Müller, H., Seiler, W., and Sievering, H.: On the dry deposition of ozone and reactive nitrogen species, Atmos. Environ., 29, 3209-3231, 1995.

Kunhikrishnan, T., Lawrence, M. G., von Kuhlmann, R., Richter, A., Ladstätter-Weissenmayer, A., and Burrows, J. P.: Analysis of tropospheric $\mathrm{NO}_{\mathrm{x}}$ over Asia using the model of atmospheric transport and chemistry (MATCH-MPIC) and GOME-satellite observations, Atmos. Environ., 38, 581-596, 2004.

Leue, C., Wenig, M., Wagner, T., Klimm, O., Platt, U., and Jahne, B.: Quantitative analysis of $\mathrm{NO}_{\mathrm{x}}$ emissions from Global Ozone Monitoring Experiment satellite image sequences, J. Geophys. Res., 106, 5493-5505, 2001.

MeteoSwiss: Alpine Weather Statistics (Alpenwetterstatistik - Witterungskalender: Beschreibung der einzelnen Parameter), MeteoSwiss, Switzerland, 1985.

Nakamura, K., Kondo, Y., Chen, G., Crawford, J. H., Takegawa, N., Koike, M., Kita, K., Miyazaki, Y., Shetter, R. E., Lefer, B. L., Avery, M., and Matsumoto, J.: Measurement of $\mathrm{NO}_{2}$ by the photolysis conversion technique during the Transport and Chemical Evolution Over the Pacific (TRACE-P) campaign, J. Geophys. Res., 108, art. no. 4752, doi:10.1029/2003JD003712, 2003.

Parrish, D. D., Murphy, P. C., Albritton, D. L., and Fehsenfeld, F. C.: The measurement of the photo-dissociation rate of $\mathrm{NO}_{2}$ in the atmosphere, Atmos. Environ., 17, 1365-1379, 1983.
Richter, A. and Burrows, J. P.: Tropospheric $\mathrm{NO}_{2}$ from GOME measurements, Adv. Space Res., 29, 1673-1683, 2002.

Seinfeld, J. H. and Pandis, S. N.: Atmospheric chemistry and physics - from air pollution to climate change, John Wiley \& Sons, New York, 1998.

Spichtinger, N., Wenig, M., James, P., Wagner, T., Platt, U., and Stohl, A.: Satellite detection of a continental-scale plume of nitrogen oxides from boreal forest fires, Geophys. Res. Lett., 28, 4579-4582, 2001.

Stohl, A., Eckhardt, S., Forster, C., James, P., and Spichtinger, N.: On the pathways and timescales of intercontinental air pollution transport, J. Geophys. Res., 107, art. no. 4684, doi:10.1029/2001JD001396, 2002.

Stohl, A., Huntrieser, H., Richter, A., Beirle, S., Cooper, O. R., Eckhardt, S., Forster, C., James, P., Spichtinger, N., Wenig, T., Wagner, T., Burrows, J. P., and Platt, U.: Rapid intercontinental air pollution transport associated with a meteorological bomb, Atmos. Chem. Phys., 3, 969-985, 2003,

SRef-ID: 1680-7324/acp/2003-3-969.

Umweltbundesamt: Jahresbericht 2001 aus dem Messnetz des Umweltbundesamtes, 69, Berlin, 2002.

Warneck, P.: Chemistry of the natural atmosphere, second edition, Academic Press, London, 2000.

Wenig, M., Spichtinger, N., Stohl, A., Held, G., Beirle, S., Wagner, T., Jahne, B., and Platt, U.: Intercontinental transport of nitrogen oxide pollution plumes, Atmos. Chem. Phys., 3, 387-393, 2003 , SRef-ID: 1680-7324/acp/2003-3-387.

Wernli, H. and Davies, H. C.: A Lagrangian-based analysis of extratropical cyclones. 1 . The method and some applications, Q. J. R. Meteo., 123, 467-489, 1997.

Wiegand, A. N. and Bofinger, N. D.: Review of empirical methods for the calculation of the diurnal $\mathrm{NO}_{2}$ photolysis rate coefficient, Atmos. Environ., 34, 99-108, 2000.

Winer, A. M. and Biermann, H. W.: Long path length differential optical-absorption spectroscopy (DOAS) measurements of gaseous $\mathrm{HONO}, \mathrm{NO}_{2}$ and $\mathrm{HCHO}$ in the California south coast air basin, Res. Chem. In., 20, 423-445, 1994.

Wunderli, S. and Gehrig, R.: Influence of temperature on formation and stability of surface PAN and ozone - a 2-year field-study in Switzerland, Atmos. Environ., 25, 1599-1608, 1991.

Zellweger, C., Ammann, M., Hofer, P., and Baltensperger, U.: $\mathrm{NO}_{y}$ speciation with a combined wet effluent diffusion denuder - aerosol collector coupled to Ion chromatography, Atmos. Environ., 33, 1131-1140, 1999.

Zellweger, C., Forrer, J., Hofer, P., Nyeki, S., Schwarzenbach, B., Weingartner, E., Ammann, M., and Baltensperger U.: Partitioning of reactive nitrogen $\left(\mathrm{NO}_{\mathrm{y}}\right)$ and dependence on meteorological conditions in the lower free troposphere, Atmos. Chem. Phys., 3, 779-796, 2003,

SRef-ID: 1680-7324/acp/2003-3-779. 